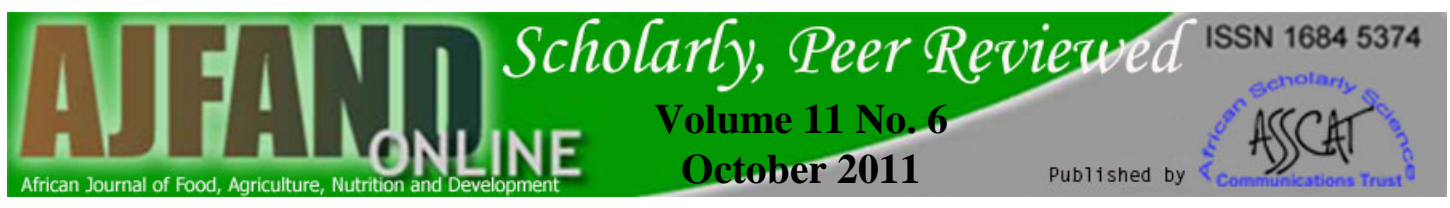

\title{
EFFICACY OF CLOVE (Syzygium aromaticum (L.) Merr and Perry) POWDER AS A PROTECTANT OF GROUNDNUT KERNELS IN STORAGE
}

$$
\text { Amoako-Attah } \mathbf{I}^{{ }^{*}} \text {, Awuah } \mathrm{RT}^{2} \text { and CM Jolly }{ }^{3}
$$

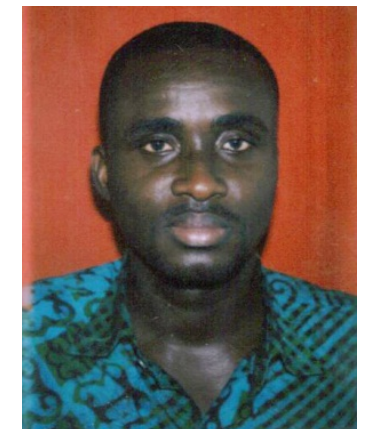

Ishmael Amoako-Attah

*Corresponding author e-mail: amoaksi@yahoo.com)

${ }^{1}$ Cocoa Research Institute of Ghana, Box 8, Akim-Tafo, Eastern Region of Ghana

${ }^{2}$ Department of Crop and Soil Sciences, Crop Protection Section, Kwame Nkrumah University of Science and Technology, Kumasi, Ghana

${ }^{3}$ Department of Agricultural Economics and Rural Sociology, Auburn University, Auburn AL, USA 


\section{ABSTRACT}

Fungi and insects infestation of groundnut kernels in storage is a serious post-harvest problem. It leads to quality deterioration and loss of market value and kernels may become contaminated with aflatoxin (AF), which has many negative health implications when consumed. Currently, botanical pesticides are highly preferred to synthetic ones during storage. Effectiveness of preserving groundnut kernels against fungi and insect damage with Syzygium aromaticum cloves (fruits) powder were assessed in the laboratory. Another experiment was conducted under farmer's storage conditions to evaluate potential of Syzygium powder to protect kernels against AF contamination. In the laboratory assessment, $3 \mathrm{~kg}$ kernel samples from sun-dried and undried pods were protected with $2 \%$ (w/w) Syzygium powder. Kernels were kept under ambient conditions in sanitised and non-sanitised rooms for six months during the dry season. Unprotected kernels were kept as control and costs of applying the treatments were estimated. The experiment was repeated in the wet season. Under farmer's storage, $50 \mathrm{~kg}$ kernel lots of 6 and $9 \%$ initial storage moisture contents were protected with $2 \%$ (w/w) Syzygium powder. Kernel lots stored without Syzygium powder served as control. These were packaged in interlaced polypropylene bags (IPPB) or polyethylene bags (PB) and stored in a farmer's barn on farm. In dry and wet seasons, fungi colonised all kernels stored in laboratory from undried pods completely at three months. Pod drying costs GHథ 8.99 (GH $\$ 0.82=\$$ US1) and it was cost effective against fungi infection in dry season. Protecting kernels with Syzygium powder was estimated at GH\& 17.87/100 kg lot and under the humid conditions in wet season, it proved cost effective against fungi infection. However, insect damage to the kernels was always higher after three months. Insects damage and fungi colonisation of kernels packaged in either PB or IPPB were reduced significantly $(\mathrm{P} \leq 0.05)$ at three months storage under farmer's conditions, when they were protected with Syzygium powder. Aflatoxins do not use abbreviation at beginning of sentence were not detected in the kernels prior to storage. At three months, however, Syzygium-protected kernels had AF levels ranging between 0 and $29.30 \mu \mathrm{g} / \mathrm{kg}$ compared to $27.5-84.0 \mu \mathrm{g} / \mathrm{kg}$ associated with unprotected kernels. Syzygium powder applied at $2 \%(\mathrm{w} / \mathrm{w})$ was effective against fungi colonisation, insect infestation and subsequent AF contamination of kernels in storage. However, the kernels should be stored for three months.

Key words: Groundnut, Storage, Mouldiness, Aflatoxin, Syzygium powder 


\section{INTRODUCTION}

Groundnut (Arachis hypogaea L.) is an important food and oil crop grown in all the 10 regions of Ghana. Production occurs in two main growing seasons namely, the dry (minor) season characterised by long dry periods of low humidity from August to March and the wet (major) season which starts in April to July and is a period of high rainfall and high relative humidity. According to FAO [1], Ghana produced a total of $440000 \mathrm{MT}$ of groundnut in 2007 and presently, it is the third largest producer of the crop in Africa after Nigeria and Sudan. A serious constraint to production, however, is insects and fungi colonisation of the kernels during storage [2]. This leads to quality deterioration and loss of market value, which negatively affects livelihood of groundnut producers. Such kernels may also become contaminated with a mycotoxin called aflatoxin (AF), if colonising fungi include Aspergillus flavus and A. parasiticus [3]. Aflatoxin consumption in humans and animals has been associated with several health problems endangering food security in producer countries [4-8].

Currently, search for protectants to protect stored kernels against fungi and insects infestation focuses on agro-botanicals as preference to synthetic chemicals, which have adverse effects on human and the environment. Most botanicals have no residual toxicity, are environmentally safe and easily biodegradable [9]. Such plant materials have been screened in many countries and recommended for use in storage [10-13]. In Ghana, Awuah and Ellis [14] screened plant powders from Syzygium aromaticum clove and Ocimum gratissimum (wild basil) leaves at $3 \%(\mathrm{w} / \mathrm{w})$ against storage pests of groundnut kernels. Syzygium powder was found most efficacious during a six months storage study. Cost of using Syzygium powder as a protectant to store groundnut kernels is, however, not known. Potential of the plant powder to control AF contamination also remains to be studied. Previously, groundnut storage studies were conducted in one groundnut growing season. A study in both dry and wet seasons should be conducted to ascertain whether kernels protection with Syzygium powder is possible under the two conditions. This study, thus, evaluated cost and effectiveness of using Syzygium powder to preserve groundnut kernels against fungi and insect damage in the dry and the wet seasons. Large quantities (50 kg lots) of Syzygiumprotected kernels stored under farmers' conditions were also evaluated for AF accumulation.

\section{MATERIALS AND METHODS}

\section{Post-harvest handling of groundnut pods}

Groundnut pods, which had been subjected to the following post- harvest handlings after harvesting (pulling) in the dry (minor) season were used: (i) inverted windrowing in the field for one week followed by stripping and further sun-drying of pods on interlaced polypropylene mats at Kwame Nkrumah University of Science and Technology (KNUST) for three weeks; (ii) No windrowing (leaving pulled plants in the field at random) for one week followed by stripping and further drying of pods on interlaced polypropylene mats at KNUST for three weeks; (iii) immediately stripping and drying of pods on interlaced polypropylene mats at KNUST for four weeks; and (iv) immediately stripping of pods and storage in interlaced polypropylene sacks 
without drying for four weeks (control). The pods were shelled, sorted and moisture content of clean kernels gravimetrically determined by oven-drying $10 \mathrm{~g}$ representative samples to a constant weight for use. The entire experiment was repeated in the wet (major) season. Aspects of the study have been reported by Amoako-Attah et al. [15].

\section{Preparation of Syzygium aromaticum powder}

S. aromaticum, whose cloves (fruits) powder was used, is a tropical evergreen tree found commonly in eastern parts of Africa such as Tanzania. The cloves have a characteristic pleasant fragrance and a slightly hot taste. It is mostly imported and sold on Ghanaian markets as spice. It is widely used to prepare local and foreign cuisines and it also has several medicinal uses. Dried Syzygium cloves were bought from Kumasi central market and milled with a five-inch junior laboratory mill (Cristy and Norris Ltd., Chemsford, England). The powder obtained was stored in refrigerator in clean plastic containers until needed.

\section{Protection and storage of kernels in the laboratory rooms}

Clean kernels from each post-harvest pod handling were divided into four, $3 \mathrm{~kg}$ lots and each lot placed in interlaced polypropylene bag $\left(516 \mathrm{~cm}^{2}\right.$ in size). Two of the lots were each mixed thoroughly with $60 \mathrm{~g}$ of Syzygium clove powder $(2 \% \mathrm{w} / \mathrm{w}$ rate, powder: kernel) while the other two were not protected. All four bags were sealed by sewing the top, leaving $3 \mathrm{~cm}$ head space. Two of the sealed bags, one containing Syzygium protected kernels and the other with unprotected kernels were placed on 120 x 70 x $10 \mathrm{~cm}$ creosote-treated wooden pallets in a sanitised room $\left(15.86 \mathrm{~m}^{3}\right.$ room thoroughly sprayed with Malathion (w.p) at a rate of $50 \mathrm{~g}$ in $1 \mathrm{~L}$ water, $25 \%$ a.i.). The other set of two bags, with the protected and the unprotected kernels, was stored on the floor in an adjacent room $\left(15.86 \mathrm{~m}^{3}\right)$ where no sanitary precautions were taken. The experiment was, thus, in a $2 \times 2 \times 4$ factorial combination (shown in Fig. 1) with three replications. There were two levels of kernel protection method (protection with Syzygium powder vs. unprotected) and two levels of storage environment (sanitised vs. non-sanitised). There were four levels of post-harvest pod handling methods viz (i) inverted windrow (ii) random windrow (iii) immediate stripping and drying and (iv) no drying. The bags were kept under ambient room conditions in $12 \mathrm{~h}$ diffused day light and $12 \mathrm{~h}$ darkness in a completely randomized design during the dry season. The kernel protection and storage were repeated in the wet season. 


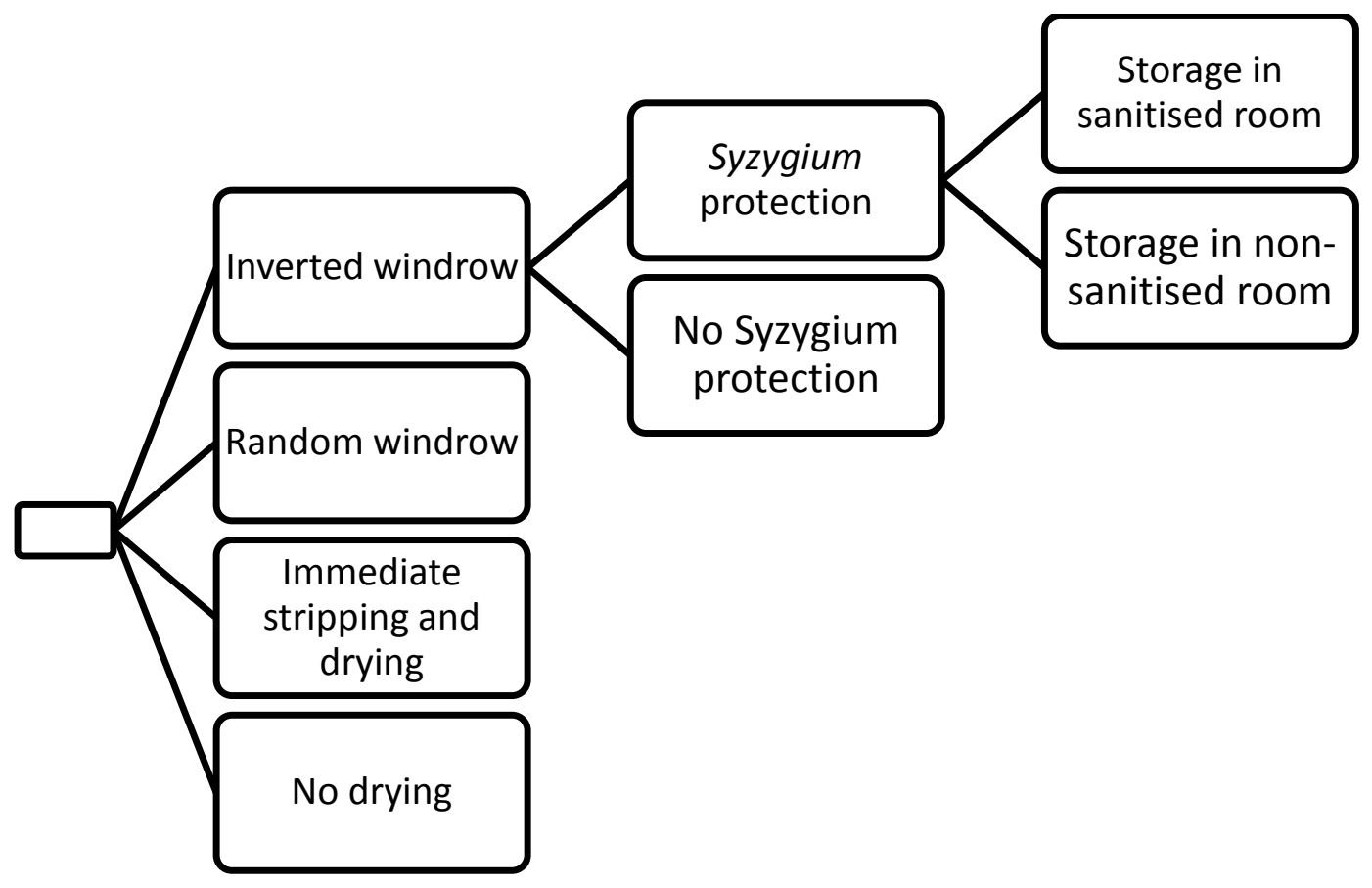

Figure 1: Schematic illustration of treatment combinations

\section{Estimation of cost and weather conditions during storage}

Cost of labour and materials for storing the kernels was estimated using market prices of Syzygium cloves, insecticides, sacks, pallet and wages of 2003/2004. Cost was based on $100 \mathrm{~kg}$ pods or $100 \mathrm{~kg}$ kernels. Re-usability of the various materials was estimated based on experience from past usage. Average temperature, relative humidity and total rainfall for the entire six months storage period was obtained from the weather station of the Department of Mechanical Engineering, KNUST located about $0.5 \mathrm{~km}$ from the storage site.

\section{Groundnut kernels preservation on-farm}

Groundnut kernels were obtained from the market and the clean ones sorted out for use. Their moisture and AF contents were determined. Aflatoxin levels of the kernel were determined using a method described by Pons [16]. Toxins in the kernels were extracted with methanol - $10 \% \mathrm{NaCl}(4: 1)$. AFs B1, B2, G1 and G2 in the purified extract were separated and quantified by normal phase high pressure liquid chromatographic (HPLC) method and detected through fluorescence on a silica gelpacked flow cell. Total AF levels were obtained by adding the values for the various AFs. Kernel moisture content was gravimetrically determined as described previously. The clean kernels were sun-dried to approximately $6 \%$ moisture content and divided into two equal lots. One lot was spread out on polyethylene sheet and its moisture content adjusted to approximately $9 \%$ by spraying with fine mist of distilled water. The $9 \%$ moisture content kernel lots were divided into four, $50 \mathrm{~kg}$ sub-lots. Two of the lots were placed in storage bags made from polyethylene sheet (PB) and the other two in bags made from interlaced polypropylene fabric (IPPB). Each storage bag was approximately $80 \times 60 \mathrm{~cm}$. The contents of one bag from the polyethylene 
sheet and the polypropylene fabric were treated with Syzygium powder by thoroughly mixing with $1 \mathrm{~kg}$ powder $(2 \% \mathrm{w} / \mathrm{w})$ while the contents of the other two bags were not treated. Similarly, the $6 \%$ moisture content kernel lot was sub-divided, bagged and treated as described previously. The bags were sealed by tying their open ends with nylon twines and arranged in complete randomised design in a farmer's barn for six months under ambient conditions $\left(25-32{ }^{\circ} \mathrm{C}\right)$. The experiment was in factorial with two levels of initial kernels storage moisture content (6\% vs. 9\%), two levels of packaging material (IPPB vs. PB) and two levels of kernels protection (Syzygium powder protected vs. unprotected). Each treatment was replicated three times.

\section{Determination of mouldiness, insect population and damaged kernels}

Three replicate kernel samples (100 kernels/sample) were randomly taken from each of the bags stored in laboratory and on-farm at three and six months using a spoonlike sampler. However, each replicate sample in the on-farm storage consisted of 15 sub-samples taken from the top, middle and bottom of each bag. Adult insects were sieved into a Kilnar jar containing a piece of chloroform-soaked cotton wool, counted and expressed as a number. The insects were identified at the Entomology Section of Crop and Soil Sciences Department, KNUST. Kernels were examined under dissecting microscope (x4) and those with insects feeding hole or holes were considered damaged. Any kernel with superficial fungal growth was considered mouldy and expressed as a percentage of total kernels sampled. Representative kernels from each bag were split opened at six months and internal fungal growth assessed. Kernel moisture content was gravimetrically determined as described previously. Kernels AF contents were assessed at three months.

\section{Data analysis}

Percentages (except moisture contents) were arcsine transformed $\left(\operatorname{Sin}^{-1} \sqrt{X}\right.$, where $X=$ percent value) and insect numbers were square root transformed $(\sqrt{ } \mathrm{Y}+0.5$, where $\mathrm{Y}=$ number of count) before analysis. Analysis of variance was performed on the data with MSTAT C computer package (Michigan State University). Differences in the means were compared using least significant difference (Lsd) at $\mathrm{p} \leq 0.05$.

\section{RESULTS}

\section{Groundnut kernel preservation with Syzygium powder in the laboratory}

Pod drying was effective against fungal colonization of kernels, however, specific trends were not observed in the different methods (windrow drying or mat-drying) used. Fungi colonising the kernels were Aspergillus niger, A. flavus, A. tamarii, Rhizoctonia stolonifer, species of Penicillium and Trichoderma. They were more prevalent in the wet season than the dry season. . Insect pests inventoried in the storage period were groundnut seed-beetle, Caryedon serratus and a more commonly encountered red-flour beetle, Tribolium castaneum. In the dry season, insect numbers in kernels sampled from sanitised environment, when the kernels were protected with Syzygium powder were 0.0 to 2.6/100 kernel lot at three months. This contrasted the values of 1.0-3.6/100 kernel lot obtained under the same storage environment when kernels were not protected with Syzygium powder (Table 1). Under non-sanitised environment, insect numbers from Syzygium-protected kernels were 1.0-2.3 compared

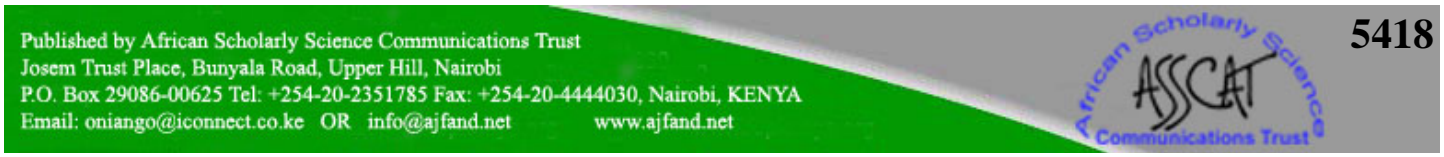


to 2.4-8.9 values obtained for the unprotected ones (Table 1). Insect damage to kernels generally reflected insect population levels (Table 1). Results obtained at six months showed similar trends of Syzygium powder protection against insects and their damage. Fungi infection associated with Syzygium-protected kernels in the wet season ranged from 1.3 to $4.1 \%$ at three months. These values were significantly $(\mathrm{P} \leq 0.05)$ lower than 15.8-19.9 \% obtained when kernels were not protected with Syzygium powder (Table 1). Kernels from undried pods were completely mouldy at three months. All kernels stored in wet season without Syzygium powder as protectant were completely mouldy at six months but the Syzygium-protected lots in sanitised and non-sanitised environments were, respectively, 5.6-5.9 \% and 8.9-10.2 \% mouldy during the same period (Table 2).

\section{Economics of preserving kernel with Syzygium powder in sanitised laboratory room}

Drying $100 \mathrm{~kg}$ of groundnut pods costs GHథ 8.99 (GHథ 0.82p = \$ US1) and shelling with motor-powered Tek groundnut cracker was estimated at GH\$ 0.55p. Sanitising (cleaning and treating) a $15.86 \mathrm{~m}^{3}$ storage room with insecticide, Malathion (w.p) at a rate of $50 \mathrm{~g} / \mathrm{L}$ of water, costs $\mathrm{GH} 40.20 \mathrm{p}$. Constructing and fitting a 150 × 80 x $10 \mathrm{~cm}$ creosote-treated wooden pallet into the sanitised room cost GH\$ 5.30. One pallet could carry $200 \mathrm{~kg}$ kernel lot and it was estimated to be reusable for five seasons so cost per each season's use for storing $100 \mathrm{~kg}$ kernels was GH4 0.53p. Cost of applying $2 \mathrm{~kg}$ Syzygium powder to $100 \mathrm{~kg}$ groundnut kernels (2\% w/w rate) was GHC 17.72. This consisted of cost of dried Syzygium cloves and labour for milling, applying the powder and sealing a storage bag. One storage bag (IPPB) costs GH4 $0.30 \mathrm{p}$ to store $100 \mathrm{~kg}$ kernels. A bag was estimated to be reusable for two seasons, so cost for each season's use was GHథ 0.15p. Treating $100 \mathrm{~kg}$ kernels with Syzygium powder for storage was GHÆ 17.87 (Table 3). Storing $100 \mathrm{~kg}$ kernels from sun-dried pods in a non-sanitised room without any protection was GH\$ 9.54. When such kernels were protected with Syzygium powder and stored in a sanitised room, the cost increased to GHథ 28.14 (Table 3).

\section{Weather data and kernels moisture contents during storage in the laboratory rooms}

In the first three months of storage, total rainfall, average $\mathrm{RH}$ and temperature were, respectively, $236.8 \mathrm{~mm}, 86.4 \%$ and $27.4{ }^{\circ} \mathrm{C}$ in the dry season and the values were, respectively, $302.5 \mathrm{~mm}, 90.6 \%$ and $25.6{ }^{\circ} \mathrm{C}$ in the wet season. During the subsequent three months, total rainfall, average relative humidity and temperature were, respectively, $850 \mathrm{~mm}, 79.0 \%$ and $26{ }^{\circ} \mathrm{C}$ in the dry season and the values were, respectively, $966 \mathrm{~mm}, 78.5 \%$ and $26.2{ }^{\circ} \mathrm{C}$ in the wet season. In the dry season, kernel moisture contents associated with kernels from dried pods were 8.3-8.9 \% at three months and 7.0-7.6 \% at six months. The values obtained for kernels from undried pods during the same periods were, respectively, 8.6-9.5 \% and 7.5-8.1\% (Table 4). With pods dried in the wet season, moisture contents of the kernels at three months storage were between 9.6 and $9.8 \%$ compared to the values of 9.7-9.9\% obtained when kernels were stored from undried pods (Table 4). 
Preservation of shelled groundnut with Syzygium powder on-farm

At three months, average insect number associated with Syzygium-protected kernels in IPPB were 0.4/100 kernel sample for $6 \%$ initial storage moisture content (ISMC) kernels and 1.2 for $9 \%$ moisture content kernels. These values were significantly lower than the 3.8 (6 \% ISMC) and 4.5 (9 \% ISMC) values obtained for kernels that were not protected with Syzygium powder (Table 5). A similar trend of Syzygium powder protection was observed for kernels stored in PB (Table 5). Average insect numbers at six months were higher in the IPPB than PB but in both storage bags, the numbers were reduced when the kernels were protected with Syzygium powder (Table 5). Protection of kernels with Syzygium powder significantly reduced the insect damage in both $6 \%$ and $9 \%$ ISMC kernels at three months (Table 5). At six months, damaged kernels in $6 \%$ and $9 \%$ ISMC in both IPPB and PB ranged between 21.0$34.1 \%$ but the levels were significantly $(\mathrm{P} \leq 0.05)$ reduced to $14.0-20.1 \%$ where Syzygium powder was used. Syzygium powder application also effectively reduced kernel mouldiness at three months and effect of the powder was more pronounced in PB (Table 5). At six months, however, the powder could not protect $9 \%$ ISMC kernels stored in PB from decomposing and this affected accurate assessment of insect damage so kernels damage were not determined (Table 5). With their counterparts stored in IPPB, the powder was effective resulting in only $8.2 \%$ mouldy kernels. Fungal infection of $6 \%$ ISMC kernels stored in PB was generally higher than that associated with IPPB (Table 5). No AF was detected in the kernels prior to storage. The toxin levels were generally higher in kernel lots stored in PB than those in IPPB (Table 5). Kernels stored at low ISMC in combination with Syzygium powder protection resulted in the lowest AF values of $0-1.6 \mu \mathrm{g} / \mathrm{kg}$ at three months (Table 5). Without protection from Syzygium powder, AF contents of $27.5-84.0 \mu \mathrm{gg} / \mathrm{kg}$ were obtained. The AF levels associated with kernels protected with Syzygium powder during the three months storage were 0 to $29.3 \mu \mathrm{g} / \mathrm{kg}$ and these values were within FAO/WHO acceptable limits of $30 \mu \mathrm{g} / \mathrm{kg}$ (Table 5).

\section{DISCUSSION}

Cost and effectiveness of using Syzygium powder to protect groundnut kernels in storage against fungi and insects infestation and subsequent AF contamination were investigated. In the study, only $3.6 \%$ of kernels from dried pods showed superficial fungal growth after six months storage in dry season without protectant. This is attributed to effective pod drying and generally dry weather during storage, which ensured that the kernels initial storage moisture content (ISMC), which was less than $8 \%$, known to be effective against fungi growth on groundnut, was maintained [17]. This finding corresponds to that of Christensen [18] who recorded no microbial growth on cereal grains stored and maintained at less than $7 \%$ moisture and in equilibrium with atmospheric relative humidity. Kernels from undried pods were all mouldy after three months and financially constituted a total loss. Therefore, pod drying which cost $\$ 8.99 / 100 \mathrm{~kg}$ pod lot and have been reported as cost effective in controlling fungi infection of groundnut kernels should be practiced [15]. Mouldiness of kernels from dried pods in the wet season was high because prevailing weather at three months storage was humid (Av. $\mathrm{RH}=90.60 \%$ ), facilitating rapid rise in kernel moisture content which favours fungal colonisation of stored products [19]. At six

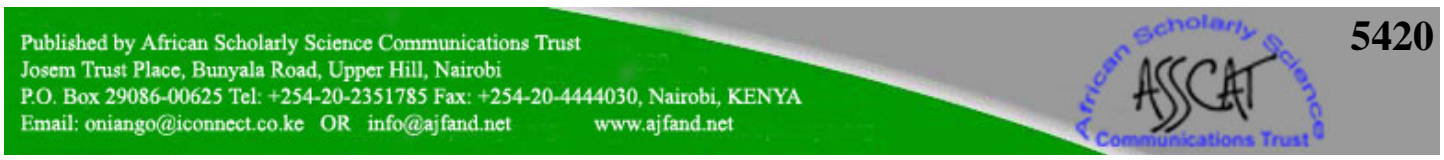


months, all the kernels stored without Syzygium powder were completely mouldy with internal fungal sporulation and discoloured cotyledons. The kernels represented total financial loss. Applying Syzygium powder cost GH\$ 17.87/100 kg kernel lot and during the period, it reduced mouldiness to $\approx 10 \%$ making the practice cost effective. Thus, under humid storage conditions, kernels should be protected with $2 \%$ (w/w) Syzygium powder.

Insect infestation of groundnut kernels in storage is always problematic. In Ghana, the main storage insect pest of groundnut is C. serratus [14]. This insect and $T$. castaneum infestation was controlled successfully with Syzygium powder. Hence, kernels should necessarily be stored with Syzygium powder in both dry and wet seasons to protect them against insects and fungi damage. Cost of controlling insect damage to kernels with Syzygium powder was uneconomical at six months because insect damage was always higher after three months. Therefore, kernels storage with Syzygium powder beyond three months is not recommended. Insects and their damage were minimised in sanitised environment relative to the non-sanitised. This was expected because as part of sanitation practice, the storage room was treated with insecticide, Malathion WP. Residual effects of the insecticide could have inhibited the activities and/or development of insects in the storage room [20]. Effective insects' reduction in sanitised rooms also resulted in lower levels of kernel mouldiness. This is because insects predispose groundnut kernels to higher fungi infection with subsequent AF contamination [21, 22]. Therefore, applying a suitable insecticide to sanitise storage environment is essential and should be incorporated into groundnut storage practices.

High potency of $S$. aromaticum powder against fungi and insects infestation is attributed to eugenol, the main bioactive compound in the plant [23, 24]. Previously, efficacy of the powder against storage pests of groundnut has always been proven with small kernel lots under laboratory storage conditions [14, 25]. This does not represent field situation where large quantities of groundnut kernels are stored in barns. In such storage places, food items such as cowpea, maize, sorghum and tuber crops may also be kept, increasing the potential for high fungi and insects infestation in the storage environment [26]. This study has shown that under such conditions, similar to those used in the current on-farm study, insects, their damage and fungi colonisation of kernels packaged in either PB or IPPB can be controlled effectively, if they are protected with Syzygium powder. However, insects and their damage were not controlled at six months regardless of storage bag and protection with Syzygium powder contrary to report by Awuah and Ellis [14]. Therefore, at $2 \%$ (w/w) Syzygium powder concentration used in the present study, storage beyond three months is not recommended because insect damage can be problematic after that period.

This study is the first report of essentially managing AF contamination of groundnut kernels under farmers' storage conditions in Ghana. Prior to storage, AF was not detected in the kernels. Toxin detected at three months was attributed to growth of aflatoxin-producing fungi such as A. flavus, which was among the isolated fungi. This confirms report that AF can only be produced when aflatoxigenic fungus grows [27]. Syzygium powder was, however, able to reduce kernels AF contamination effectively. 
Irrespective of kernels storage moisture content (6 or $9 \%$ ) and packaging material (IPPB or PB), AF levels were kept well within the acceptable limits of $30 \mu \mathrm{g} / \mathrm{kg}$ recommended by FAO/WHO for human consumption [28]. Therefore, kernels can be stored with Syzygium powder in any of the two packaging materials for three months. This will make kernels safe from both chemical residues and AF contamination.

\section{ACKNOWLEDGEMENT}

This study was funded by the USAID Peanut Collaborative Research Support Program (CRSP). 


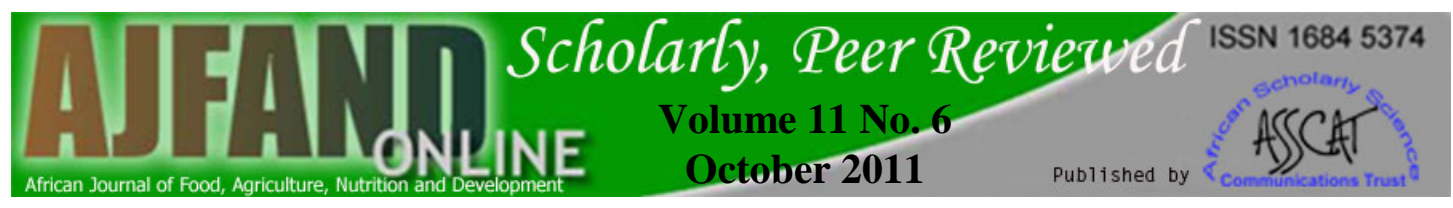

Table 1: Insect numbers, groundnut kernel damage and mouldiness at three months of storage as affected by post-harvest pod handling method, kernel protection with Syzygium powder and storage environment ${ }^{1}$

\begin{tabular}{|c|c|c|c|c|c|c|}
\hline \multirow[b]{2}{*}{ Treatment $^{2}$} & \multicolumn{2}{|c|}{ Insect number } & \multicolumn{2}{|c|}{ Damaged kernels (\%) } & \multicolumn{2}{|c|}{ Mouldy kernels (\%) } \\
\hline & $\begin{array}{c}\text { Dry } \\
\text { season }\end{array}$ & $\begin{array}{c}\text { Wet } \\
\text { season }\end{array}$ & $\begin{array}{c}\text { Dry } \\
\text { season }\end{array}$ & $\begin{array}{c}\text { Wet } \\
\text { season }\end{array}$ & $\begin{array}{c}\text { Dry } \\
\text { season }\end{array}$ & $\begin{array}{c}\text { Wet } \\
\text { season }\end{array}$ \\
\hline \multicolumn{7}{|l|}{$\underline{\text { Sanitised }}$} \\
\hline A & 1.0 & 1.5 & 5.5 & 4.3 & 0.1 & 17.6 \\
\hline B & 2.5 & 2.2 & 4.6 & 5.8 & 0.0 & 17.5 \\
\hline $\mathrm{C}$ & 3.6 & 1.1 & 3.7 & 5.9 & 0.0 & 16.8 \\
\hline $\mathrm{D}$ & 1.0 & 0.7 & 2.3 & 6.1 & 100.0 & 100.0 \\
\hline (A) & 0.3 & 0.5 & 2.5 & 2.5 & 0.0 & 1.3 \\
\hline (B) & 2.6 & 1.1 & 1.3 & 3.3 & 0.0 & 2.2 \\
\hline (C) & 0.0 & 0.9 & 1.0 & 2.9 & 0.0 & 2.6 \\
\hline (D) & 0.0 & 0.0 & 1.0 & 5.2 & 100.0 & 100.0 \\
\hline \multicolumn{7}{|l|}{ Non-sanitised } \\
\hline $\mathrm{A}$ & 8.9 & 2.8 & 7.6 & 7.3 & 0.4 & 15.8 \\
\hline B & 2.8 & 6.6 & 10.1 & 7.0 & 0.1 & 19.5 \\
\hline $\mathrm{C}$ & 8.8 & 2.6 & 16.0 & 7.3 & 0.0 & 19.9 \\
\hline $\mathrm{D}$ & 2.4 & 1.9 & 4.9 & 7.5 & 100.0 & 100.0 \\
\hline (A) & 2.3 & 2.2 & 1.9 & 3.7 & 0.0 & 2.9 \\
\hline (B) & 1.3 & 2.5 & 1.9 & 4.5 & 0.0 & 1.9 \\
\hline (C) & 1.0 & 1.1 & 2.5 & 3.1 & 0.0 & 4.1 \\
\hline (D) & 1.0 & 0.8 & 1.9 & 6.6 & 100.0 & 100.0 \\
\hline LSD (5\%) & 0.6 & 0.7 & 5.2 & 5.0 & 2.4 & 6.9 \\
\hline CV (\%) & 21.9 & 29.9 & 28.2 & 23.2 & 6.2 & 11.9 \\
\hline
\end{tabular}

${ }^{1}$ Each figure is the mean from three replicates, 100 kernel lots per treatment

${ }^{2}$ Treatments are $\mathrm{A}=$ inverted windrow drying of pulled plants for one week and further drying of pods on mats for three weeks; $\mathrm{B}=$ randomly (or non-inverted) windrow drying of pulled plants for one week and further drying of pods on mats for three weeks; $\mathrm{C}=$ harvesting, immediate stripping and drying of pods on mats for four weeks; $\mathrm{D}=$ stripping of pods and storage for four weeks without drying (control). Treatments represented in parentheses are Syzygium-protected kernels while those without parentheses are unprotected kernels. Sanitised and non-sanitised are kernel storage environment conditions. 


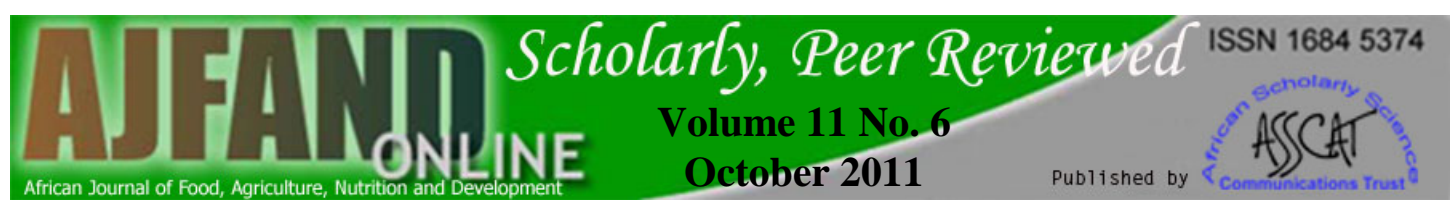

Table 2: Insect numbers, groundnut kernel damage and mouldiness at six months of storage as affected by post-harvest pod handling method, kernel protection with Syzygium powder and storage environment ${ }^{1}$

\begin{tabular}{|c|c|c|c|c|c|c|}
\hline \multirow{2}{*}{ Treatment $^{2}$} & \multicolumn{2}{|c|}{ Insect number } & \multicolumn{2}{|c|}{ Damaged kernels (\%) } & \multicolumn{2}{|c|}{ Mouldy kernels (\%) } \\
\hline & $\begin{array}{c}\text { Dry } \\
\text { season }\end{array}$ & $\begin{array}{c}\text { Wet } \\
\text { season }\end{array}$ & $\begin{array}{c}\text { Dry } \\
\text { season }\end{array}$ & $\begin{array}{c}\text { Wet } \\
\text { Season }\end{array}$ & $\begin{array}{c}\text { Dry } \\
\text { season }\end{array}$ & $\begin{array}{c}\text { Wet } \\
\text { Season }\end{array}$ \\
\hline \multicolumn{7}{|l|}{$\underline{\text { Sanitised }}$} \\
\hline A & 11.7 & 0.3 & 22.3 & 1.3 & 1.6 & 100.0 \\
\hline B & 6.5 & 2.3 & 22.0 & 3.9 & 1.0 & 100.0 \\
\hline $\mathrm{C}$ & 12.6 & 1.6 & 20.5 & 4.3 & 2.6 & 100.0 \\
\hline $\mathrm{D}$ & 3.5 & 1.0 & 19.4 & 3.8 & 100.0 & 100.0 \\
\hline (A) & 3.5 & 7.4 & 17.9 & 11.2 & 0.1 & 5.9 \\
\hline (B) & 3.5 & 10.7 & 13.5 & 10.8 & 0.1 & 5.6 \\
\hline (C) & 4.6 & 5.6 & 13.3 & 16.5 & 0.4 & 5.6 \\
\hline (D) & 2.2 & 0.0 & 11.0 & 7.9 & 100.0 & 100.0 \\
\hline \multicolumn{7}{|l|}{ Non-sanitised } \\
\hline A & 15.3 & 3.7 & 21.9 & 1.3 & 3.6 & 100.0 \\
\hline$\stackrel{B}{C}$ & $\begin{array}{c}12.2 \\
4.9\end{array}$ & $\begin{array}{l}2.6 \\
4.7\end{array}$ & $\begin{array}{l}33.9 \\
25.9\end{array}$ & $\begin{array}{l}3.8 \\
1.3\end{array}$ & $\begin{array}{l}1.8 \\
0.4\end{array}$ & $\begin{array}{l}100.0 \\
100.0\end{array}$ \\
\hline $\mathrm{D}$ & 7.8 & 2.5 & 28.2 & 1.0 & 100.0 & 100.0 \\
\hline (A) & 6.5 & 11.0 & 17.1 & 8.6 & 1.3 & 9.8 \\
\hline (B) & 9.8 & 12.3 & 23.3 & 23.6 & 1.0 & 10.2 \\
\hline (C) & 5.2 & 10.9 & 13.3 & 18.5 & 1.5 & 8.9 \\
\hline (D) & 3.6 & 6.2 & 22.3 & 19.7 & 100.0 & 100.0 \\
\hline LSD (5\%) & 0.9 & 0.8 & 6.9 & 4.7 & 3.5 & 1.8 \\
\hline CV (\%) & 21.0 & 23.0 & 15.7 & 18.2 & 7.9 & 1.7 \\
\hline
\end{tabular}

${ }^{1}$ Each figure is the mean from three replicates, 100 kernel lots per treatment.

${ }^{2}$ Treatments are $\mathrm{A}$ = inverted windrow drying of pulled plants for one week and further drying of pods on mats for three weeks; $\mathrm{B}=$ randomly (or non-inverted) windrow drying of pulled plants for one week and further drying of pods on mats for three weeks; $\mathrm{C}=$ harvesting, immediate stripping and drying of pods on mats for four weeks; $\mathrm{D}=$ stripping of pods and storage for four weeks without drying (control). Treatments represented in parentheses are Syzygium-protected kernels while those without parentheses are unprotected kernels. Sanitised and non-sanitised are kernel storage environment conditions. 


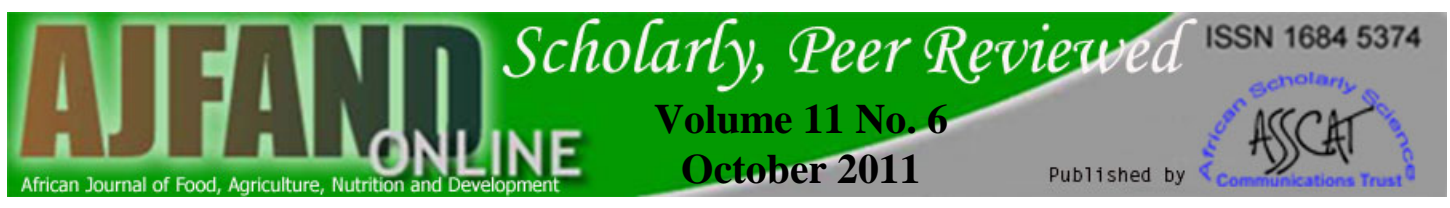

Table 3: Cost (GH \&) of various practices used in preserving groundnut kernels ${ }^{1}$

\begin{tabular}{|c|c|c|c|c|c|c|}
\hline \multirow[b]{2}{*}{ Practice $^{2}$} & \multirow{2}{*}{$\begin{array}{l}\text { Pod } \\
\text { drying }\end{array}$} & \multirow{2}{*}{$\begin{array}{c}\text { Pod } \\
\text { shelling }\end{array}$} & \multirow{2}{*}{$\begin{array}{l}\text { Syzygium } \\
\text { treatment }\end{array}$} & \multicolumn{2}{|c|}{ sanitisation } & \multirow[b]{2}{*}{ Total } \\
\hline & & & & Cleaning & Pallet & \\
\hline \multicolumn{7}{|l|}{$\underline{\text { Sanitised }}$} \\
\hline Drying; no Syzygium & 8.99 & 0.55 & 0 & 0.20 & 0.53 & 10.27 \\
\hline No drying; no Syzygium & 0 & 0.55 & 0 & 0.20 & 0.53 & 1.28 \\
\hline Drying; Syzygium & 8.99 & 0.55 & 17.87 & 0.20 & 0.53 & 28.14 \\
\hline No drying; Syzygium & 0 & 0.55 & 17.87 & 0.20 & 0.53 & 19.15 \\
\hline \multicolumn{7}{|l|}{ Non-sanitised } \\
\hline Drying; no Syzygium & 8.99 & 0.55 & 0 & 0 & 0 & 9.54 \\
\hline No drying; no Syzygium & 0 & 0.55 & 0 & 0 & 0 & 0.55 \\
\hline Drying; Syzygium & 8.99 & 0.55 & 17.87 & 0 & 0 & 27.41 \\
\hline No drying; Syzygium & 0 & 0.55 & 17.87 & 0 & 0 & 18.42 \\
\hline
\end{tabular}

${ }^{1}$ Cost estimations based on $100 \mathrm{~kg}$ lots. (GHÆ 0.82p = \$ US1)

${ }^{2}$ Practice $=$ sanitised and non-sanitised are kernel storage environment; drying involved either mat-drying alone for four weeks or windrow-drying of pods for one week followed by mat-drying for three weeks before shelling, Syzygium powder was applied at $2 \%(\mathrm{w} / \mathrm{w})$ rate. 
Table 4: Per cent Moisture Content (MC) of groundnut kernels as affected by post-harvest pod handling method, kernel protection with Syzygium powder and storage environment ${ }^{1}$

\begin{tabular}{|c|c|c|c|c|c|c|}
\hline \multirow{2}{*}{ Treatment } & \multicolumn{3}{|c|}{ Dry season } & \multicolumn{3}{|c|}{ Wet season } \\
\hline & $\begin{array}{l}\text { Initial } \\
\mathrm{MC}^{2}\end{array}$ & $\begin{array}{c}\text { Three } \\
\text { months }\end{array}$ & $\begin{array}{c}\text { Six } \\
\text { month }\end{array}$ & $\begin{array}{l}\text { Initial } \\
\mathrm{MC}^{2}\end{array}$ & $\begin{array}{l}\text { Three } \\
\text { months }\end{array}$ & Six months \\
\hline A & 7.7 & 8.9 & 7.6 & 7.1 & 9.7 & 10.2 \\
\hline B & 7.7 & 8.9 & 7.3 & 7.2 & 9.7 & 10.3 \\
\hline $\mathrm{C}$ & 7.4 & 8.9 & 7.7 & 7.5 & 9.7 & 10.4 \\
\hline $\mathrm{D}$ & 7.8 & 9.5 & 8.1 & 7.8 & 9.8 & 11.0 \\
\hline (A) & 7.5 & 8.5 & 7.2 & 7.0 & 9.7 & 9.3 \\
\hline (B) & 7.6 & 8.7 & 7.1 & 7.2 & 9.7 & 9.4 \\
\hline (C) & 7.4 & 8.8 & 7.6 & 7.1 & 9.6 & 9.9 \\
\hline (D) & 7.6 & 9.2 & 7.9 & 7.5 & 9.7 & 9.8 \\
\hline \multicolumn{7}{|l|}{ Non-sanitised } \\
\hline $\mathrm{A}$ & 7.7 & 8.3 & 7.1 & 7.1 & 9.7 & 10.5 \\
\hline B & 7.7 & 8.8 & 7.2 & 7.2 & 9.8 & 11.0 \\
\hline $\mathrm{C}$ & 7.4 & 8.7 & 7.5 & 7.5 & 9.8 & 10.6 \\
\hline $\mathrm{D}$ & 7.8 & 8.6 & 7.8 & 7.8 & 9.9 & 12.7 \\
\hline (A) & 7.5 & 8.8 & 7.0 & 7.0 & 9.7 & 10.2 \\
\hline (B) & 7.6 & 8.9 & 7.2 & 7.2 & 9.7 & 9.7 \\
\hline (C) & 7.4 & 8.9 & 7.1 & 7.1 & 9.6 & 10.0 \\
\hline (D) & 7.6 & 9.0 & 7.5 & 7.5 & 9.8 & 10.2 \\
\hline LSD (5\%) & 0.3 & 0.4 & 0.3 & 0.2 & 0.03 & 0.9 \\
\hline CV (\%) & 2.9 & 3.0 & 2.3 & 1.9 & 0.2 & 5.3 \\
\hline
\end{tabular}

${ }^{1}$ Treatments are $\mathrm{A}=$ inverted windrow drying of pulled plants for one week and further drying of pods on mats for three weeks; B = randomly (or non-inverted) windrow drying of pulled plants for one week and further drying of pods on mats for three weeks; $\mathrm{C}$ = harvesting, immediate stripping and drying of pods on mats for four weeks; $\mathrm{D}=$ stripping of pods and storage for four weeks without drying (control). Treatments represented in parentheses are Syzygium-protected kernels while those without parentheses are unprotected kernels. Sanitised and non-sanitised are kernel storage environment conditions

${ }^{2}$ Moisture contents of kernels prior to storage. 


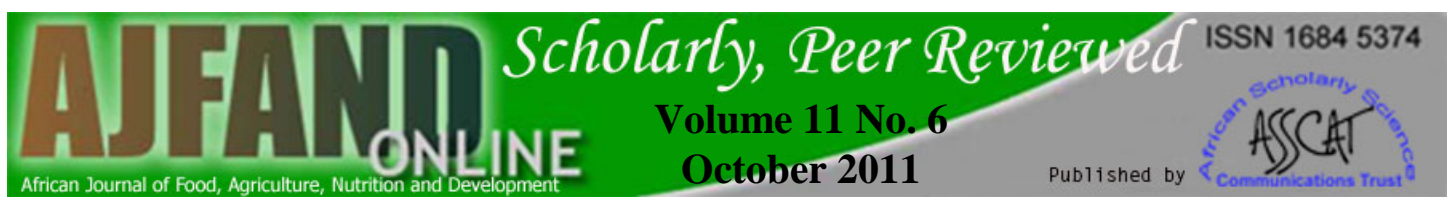

Table 5: Effect of some post-harvest treatments on four storage parameters of groundnut with $6 \%$ and $9 \%$ kernel moisture content under field conditions $^{1}$

\begin{tabular}{|c|c|c|c|c|}
\hline Treatment & Insect number & $\begin{array}{l}\text { Damaged Kernels } \\
(\%)^{2}\end{array}$ & $\begin{array}{c}\text { Mouldy Kernels } \\
\text { (\%) }\end{array}$ & $\begin{array}{c}\mathrm{AF}^{3} \\
(\mu \mathrm{g} / \mathrm{kg})\end{array}$ \\
\hline \multicolumn{5}{|l|}{$\underline{\mathrm{IPPB}}$} \\
\hline $9.0 \%+$ Syzygium & $1.2(13.6)$ & $7.7(20.1)$ & $3.7(8.2)$ & 25.1 \\
\hline 9.0 \% (no Syzygium) & $4.5(14.3)$ & $22.5(34.1)$ & $6.7(20.5)$ & 36.2 \\
\hline $6.0 \%+$ Syzygium & $0.4(11.3)$ & $3.4(18.66)$ & $1.0(4.8)$ & ND \\
\hline 6.0 \% (no Syzygium) & $3.8(16.0)$ & $20.8(32.23)$ & $3.2(19.8)$ & 27.5 \\
\hline \multicolumn{5}{|l|}{$\underline{\mathrm{PB}}$} \\
\hline $9.0 \%+$ Syzygium & $0.8(1.6)$ & $4.3(-)$ & $3.4(100)$ & 29.3 \\
\hline 9.0 \% (no Syzygium) & $3.6(1.3)$ & $20.8(-)$ & $45.7(100)$ & 64.0 \\
\hline $6.0 \%+$ Syzygium & $0.3(7.6)$ & $3.2(14.0)$ & $1.5(4.9)$ & 1.6 \\
\hline 6.0 \% (no Syzygium) & $3.7(10.0)$ & $13.4(21.0)$ & $24.0(32.6)$ & 84.0 \\
\hline $\operatorname{LSD}(5 \%)$ & $0.05(0.5)$ & $0.3(1.1)$ & $0.6(0.7)$ & NA \\
\hline CV (\%) & $1.9(11.8)$ & $1.0(3.4)$ & $2.2(1.1)$ & NA \\
\hline
\end{tabular}

${ }^{1}$ Each figure is the mean of three replicates. Assays were made at 3 and 6 months (6 months values in parentheses)

${ }^{2}$ - indicates that damage could not be assessed

${ }^{3} \mathrm{AF}=$ aflatoxin levels (determined at 3 months only). AF before storage $=0$; $\mathrm{ND}=$ none detected; NA= not applicable. 


\section{REFERENCES}

1. FAO. Food and Agricultural Organisation of the United Nations Statistical Database 2009. http:// www. Faostat.com (Accessed 6/11/09).

2. Atuahene-Amankwa G, Hossain MA and MA Assibi Groundnut production and improvement in Ghana. Summary Proceedings of the first ICRISAT Regional Groundnut Meeting for West Africa, 13-16 September 1988. ICRISAT Sahelian Center, Niamey, Niger. ICRISAT Patancheru, India, 1990.

3. Hesseltine CW Global Significance of Mycotoxins. In: PS Steyn and R Vleggaar (Eds). Mycotoxins and Phycotoxins. Elsevier Amsterdam, Netherlands, 1986: 1-18.

4. Ozurk M $\mathrm{P}^{53}$ mutation in hepatocellular carcinoma after aflatoxin exposure. Lancet 1991; 338:1356-1359.

5. Cheng CT Perak, Malaysia, mass poisoning. Tale of the nine emperor gods and rat tail noodle. America Journal of Forensic Medicine and Pathology 1992; 13: 261-263.

6. Wogan GN Aflatoxins as risk factors for hepatocellular carcinoma in humans. Cancer Research 1992; 5: 2114s-2118s.

7. Ibeh IN, Uriah $\mathbf{N}$ and JI Ogoner Dietary exposure to aflatoxin in human male infertility in Benin-City, Nigeria. International Journal of Fertility 1994; 39:208-214.

8. Jonsyn FE Intake of aflatoxin and ochratoxin by infants in Sierra Leone: possible effects on the general health of these children. J. Nutri. Envir. Med. 1999:15-22.

9. Prakash AJ and Rao Botanical pesticides in agriculture. CRC/ Lewis Publs. Boca Raton, U.S.A. 1997: 481 pp.

10. Grainge M and S Ahmed Hand Book of Plants with Pest-Control Properties. John Wiley and Sons, New York, 1988.

11. Tiwari SN Efficacy of some plant products as grain protectant against Sitophilus oryzae (L.). J. Insect Sci. 1993; 6: 158-160.

12. Agarwal A, Lal S and KC Gupta Natural products as protectants of pulses against pulse beetle. Bull. Grain Tech. 1998; 26: 154.

13. Annie-Bright A, Babu A, Ignacimuthu $\mathbf{S}$ and $\mathbf{S}$ Dom Efficacy of Andrographis paniculata Nees. on Callosobruchus chinensis L. during post harvest storage of cowpea. Ind. J. Exp. Biol. 2001; 39: 715. 
14. Awuah RT and WO Ellis Effect of some groundnut packaging methods and protection with Ocimum and Syzygium powders on kernel infection by fungi. Mycopathologia 2001; 154: 29-36.

15. Amoako-Attah I, Awuah RT, Kpodo KA, Fialor SC and CM Jolly Cost effectiveness of selected post harvest pod handling technique against damage, mouldiness and aflatoxin contamination of shelled groundnut in Ghana. J. Sci. Tech 2007; 27: 17-27.

16. Ponds WA Jr High Pressure Liquid Chromatographic determination of aflatoxins in corn. JAOAC 1979; 62: 587-594.

17. Dick KM Pest Management in Stored Groundnuts. Information Bulletin 22. ICRISAT, Patancheru, India, 1987.

18. Christensen CM Storage of Cereal Grains and their Products. Am Assoc Cereal Chem, St Paul MN, 1974; 549 pp.

19. Harman GE Mechanisms of seed infection and pathogenesis. Phytopathology 1983; 72:326-329.

20. Appert $\mathbf{J}$ The storage of food grain and seeds. The Tropical Agriculturalist. Macmillan Education Ltd, Oxford, UK, 1987; 146 pp.

21. Lynch RE and DM Wilson Relation of lesser cornstalk borer damage to peanut pods and the incidence of Aspergillus flavus. Proceedings of APRES 1984; 16:35 (abstract).

22. Bowen KL and TP Mack Relationship of damage from the lesser cornstalk borer to Aspergillus flavus contamination in peanuts. Journal of Economic Entomology 1993; 28: 29-42.

23. Hassanali A, Lwande W, Ole-Sitayo N, Moreka L, Nokoe S and A Chapya Weevil repellent constituent of Ocimum suave leaves and Eugenia caryophyllata cloves used as grains protectants in parts of Eastern Africa. Discovery and Innovation 1990; 2: 91-95.

24. Paranagama P A Analysis of Sri Lankan essential oils by gas chromatography and mass spectroscopy. ITI, Colombo, Sri Lanka, 1991.

25. Awuah RT Inhibition of fungal colonization of stored peanut kernels with products from some medicinal/culinary plants. Peanut science 1999; 26: 1317.

26. Mlambo SS, Sithole SZ and $\mathbf{R}$ Tanyongana Storage facilities in Zimbabwe and losses due to insects. In: SB Mathur and Johs Jørgensen (Eds). Seed Pathology. CTA Publishing, Netherlands, 1992: 109-116. 
27. Badii $\mathbf{F}$ and MO Moss The effect of the fungicides tridemorph, fenpropimorph and fenarimol on growth and aflatoxin production by Aspergillus parasiticus Speare. Letters in Applied Microbiology 1988; 7:3739.

28. Fraizer WC and DC Westhoff Food Microbiology ( $3^{\text {rd }}$ ed.). Tata McGrawHill Publishing Company, New Delhi, India, 1987; 540 pp. 